\title{
Predicting New Hampshire Indoor Radon Concentrations from Geologic Information and Other Covariates
}

\author{
M.G. Apte, P.N. Price, A.V. Nero, and K.L. Revzan \\ Indoor Environment Department \\ Environmental Energy Technologies Division \\ Lawrence Berkeley National Laboratory \\ Unıversity of California \\ Berkeley, CA 94720
}

May 1998

This report was supported by the Dhrector, Office of Energy Research, Office of Health and Environtmetital Research, Human Health and Life Sciences Research Diyision of the U.S. Department of Energy (DOE) under Contrat DE-AC03-76\$FO0098. 


\section{DISCLAIMER}

This document was prepared as an accoum of work sponsored by the United States Government. While this document is believed to contain conec1 information. neither the United Stales Govemmenl nor any angency 1hereof. nor the Regems of the University of California, nor any of their employees. makes any wartanty. express or implied or assumes any legal responsibility for the accuracy; completeness. or uscfulness of any information. apparatus. product. or process disclosed. or nepresents that its use u+ould not infringe privately owned rights. Reference herein to any specific commercial produch process, or service by its trade name. trademailk. manufacturer, or otherwise, does not necessarily constitute or imply its endorsement, recommendation or favoting by the United Stales Government or any agency thereof. or the Regents of the University of California. The views and opinions of amhors expressed herein do not necessinily stale or reflec1 1hose of the United Stanes Govemmem or amy agency thereof or the Regents of the University of Califomia. 


\begin{abstract}
Generalized geologic province information and data on house construction were used to predict indoor radon concentrations in New Hampstire (NH). A mixed-effects regression model was used to predict the geometric mesn (GM) short-term radon eoncentrations in 259 NH towns. Bayesian methods wert used to avoid over-fitting and to minimize the effects of small sample varialion within towns. Data from a random sarvey of stror-lerm radon measurements, individual residence butlding characteristics, along with geologic unit information, and ayerage surfact radinm concentalion by town, wese variables used in the model. Predicted town GM short-term indoor radon concentrations for delached houses with usable basements range from $34 \mathrm{~Bq} / \mathrm{m}^{3}$ (1 pCin) to $558 \mathrm{~Bq} / \mathrm{m}^{3}$ (15 pCil), with uncertainties of about 30\%. A geologic province consisting of glacial deposits and marine sediments, was associated wilh significantly elevated ratob levels, after adjustment for radium concentration, and building typt. Validation and interpretation of results are discussed.
\end{abstract}





\section{Introduction}

Radon, a radioactive gas known to cause lung cancer when present in high concentrations, is a product of padium decay in rocks and soil. Indoor radon concentrations are nectssarily strongly affected by soif radium content, soil perneability, and other geologic parameless, as well as by other paraneters that control the ease with which soil gas can enler the bujlding, the ventilation rale, and oher building characteristics. However ${ }_{+}$direct quantitative mezsuremepts of important paramelers, including geologic parameters, are not generably available, and a physical model to predict indoor concentrations based on such measurements is unavailable in any case. Past efforts to use geologic informalion to predict radon levels or to estimate "potential" radon concentralions have usually relied on conrelation of geologic festures (lypically generalized geologic provinces) with measured indoor radon concentrations, Although some of these efforts have produced useful resuls, they have suffered from shortconings such as the use of ad hoc scoring methods, failure to make testable quantitative predictions, inadequate or inconsistent handling of smatl sample variation in observed radon concentrations, and lack of measures of model fit and validation.

We have used a statistical lechnique known as Bayesian mixed effects regression to investigate the predictive power of geologic information in combination with other data related to indoor radon measurements. Bayesian methods have previously been applied to prediction of indoor radon concentrations based on dala collected in relatively sparse radon screening measuremenl suryeys (Price and others 1995. Price and Nero 1995, and Revzan and others 1996). These techniques can be used to estimale parameters, such as the geomeric mean (GM), that describe radon concentration distributions in selecteo areas. Predictions based on statistical models of this type have the potential to provide guidance as to which geographic areas requirc the most urgent attention for such measures as intensive radon monitoring of mitigation.

The analysis and results presented in this paper use Bayesian mixed-effects regression analyses to predicl the geometric mean indoor radon concentration for each of the 259 "towns" in the state of New Hampshire (NH). Note that in New Hampshíre a "town" is a political unit similar to what is known as a "township" in some other states; some "towns" contain more that one village. 


\section{Data Used for Predictive Radon Modeling in New Hampshire}

Data used in the analysis include: 1) radon "screening" measurements in 1814 dwellings selected from a stratified random sample of the state's housing stock, 2) physical characteristics of esch building coltected via questionnaire during the survey (Pirie and Haninglon 1989; Pirie and Hanington 1990), 3) radiutb content of the surface soil (Duval and others i989), and 4) the underiying geodogic characteristics of the ground upon which each New Hampstire town lies, as identified by the U.S Geological Survey (USGS) in a modified radon geology map for the stale (Gundersen and Schumann 1993).

\section{The New Hampshire fadon Survey}

Due to concern about the public health risks associated with the exposure to radon in residences, the state of New Hampshire, Division of Public Health Services conducted a stratified tandom survey of short-lem indoor radon concentrations, or "screening measuretents," during the winter months of 1988-1990 (Pirie and Hanington 1989; Pirie and Hanington 1990). Screening measurements are intended to quickly and inexpensively delermine indoor radon concentrations. They are typically conducted in the basements of houses during winter when the house is relatively well sealed, so lhey tend to overestimate annual-average living-area radon concentrations by a factor of 1.5 to 3 . We use the scteening data because they are available and because they are expected to show approximately the samk spatial pattems that would be present in long-term living-area measurements. Adjustment to calibrate screening data to predict ennualaverage living-arca concentrations is possible in principle (Price and Nero 1996), but has nol been attempted for these data.

The NH survey sample was stratified by 1) lown or city population and 2) the predominant bedrock uranium content. Participating households were selected at ratndom from within each stratum, based on telephone directory lists. Howseholds which agreed to parlicipate were mailed a radon screening measurement kil containing a charcoal absorption delector, a set of instructions, and a survey questionnaire. The participants were asked to expose the delector for three days on the "lowest livable level" of their home, which was 
usually a basement. The questionnaire obtained information about the home's construction, beating sources and usage. water suppiy, etc. Exposed charcoal detectors and completed questionnaires were relurned by mail to the analytical laboratory and survey office, respectively. Further delails of the survey design, implementation and results can be found in the survey repont cited above.

Over the three winters during which the survey was conducted, 1814 dwellings in 232 of New Hampshire's 259 towas were monitored. Overall, 27 towns were unsarmpled, five towns had only one measuremenh, and the median number of measusements per town is 6 . Only 10 towns had 30 or more measurements. For both the state as a whole and for individual towns, measurements appear to be approximately lognormally distributed (i.e. the logarithms of the measurements arc normally distributed). The number of observations and the observed town geometric means (GM) and geometric standard deviations (GSD) for a randonly selected set of towns are presented in Table 1.

Fig. I depicts the distribution of the 1814 screening measurements. The calculated GM and GSD of these measurements are $81 \mathrm{~Bq} / \mathrm{m}^{3}(2.2 \mathrm{pCil})$ and 3.01, respectively. About 31 螴 of the homes had measurements above $\$ 50 \mathrm{Bg} / \mathrm{m}^{\prime}$ ' (4 pCil), the Environmental Protection Agency's (EPA) recommended "action ievel" for Iemediation. (Recall, however, that screening measurements substantially overstate Jong-term living-area concentrations. ) About $2.5 \%$ had measurements above $740 \mathrm{~B} / \mathrm{m}^{3}$ (20 $\mathrm{pCi}$ ). The distribution of screening measurcments is approximately lognormal. Supeximposed on Fig. 1 is a lognormal curve of $\mathrm{GM}=81 \mathrm{Bg} / \mathrm{m}^{3}$ and $G S D=3.0 \mathrm{I}$.

Table 2 summarizes some characteristics of homes included in the survey. Water source is a potentially important variable, since wates drawn from a drilled arlesian well can contain high concentrations of dissolved radon, which can escape into the house whenever water is used (Nazaroff and others 1987). Radon concentrations of $4 \times 10^{6} \mathrm{~Bq} / \mathrm{m}^{3}$ or mose have been observed in some $\mathrm{NH}$ arlesian water. All of the regression analyses presented in this work have been conducted on data from the subset of 1775 bomes for which water supply information was reported. 


\section{Surface Fadium Content and Geologlcal Attributes of Now Hampshire}

The town-average surface radium content of the soil for each town was derived from digital maps from data from the National Uranium Resource Evaluation (NURE), which were processed (Duval and others 1989) to correct for various problems with the raw data NURE measurements have been found to be correlaled with mean indoor radon concentrations (Price 1996; Price and others 1995). Fig. 2 depicts the retationship between the natural logarithm of NH town radiun levels (equivalent $U$, ppm) from NURE and the natural logarithm of town GM screening meașurements $\left(\mathrm{Bq} / \mathrm{m}^{3}\right)$. The vertical enror bars indicate \pm 1 classical standard etror in the log of the town's GM. The line through the plotted points was calculated using an ordinary least-squares regression $\left(R^{2}=0.09\right)$. The poor correlation, evident in the plot and the low value of $\mathrm{R}^{2}$, is at least pastly attributable to the small sample sizes within towns, since the observed town GMs vary substantially about the true town GMs. Thus even if NURE predicted the true town GMs perfectly (i.e., the GM that would be found if cvery home in every town were to be monitored), a low somelation with observed GMs is expected. One of the goals of the present analysis is to delermine the extent to which various explanatary variables, including NURE, can be used to predict the irue town GMs.

A digitized map of generalized geologic provinces in New Hampshire was oblained from the US Geological Survcy (USGS). The provinces arc based on both bedrock geology and soil characteristics, atd were developed by Linda Gundersen and Randall Schumann of the USGS from their radon geology map for the state (Gundersen and Schumann, 1993). Table 3 lists the 9 geologic provinces which were used in oum work, and Fig. 3 shows them os a map of New Hampshire.

The geologic data were processed through a Geographic Information System (GlS) and superimposed over the lown boundaries, and the prevalence of each geologic unit within esch town was calculated. Many 10wns were found to lie on 1wo or more geologic units. For example, the prevalence of geologic units 54\}, 544, and 561 in Alexandria, NH is $48 \%, 13 \%$, and $39 \%$, respectively.

\section{Statistical Modeling Techniques}

Observed distributions of indoer radon concentrations often appear to be apptoximately lognormal, irrespeclive of scale (Nero and others 1986, Nero and others 1990; Price 1996; Price and others 1995). 
This is probably because the indor radon concentration in a home can be written as a product of factors that are not perfectly correlated (soil radium content, times emanation fraction, times soil permegbility. etc.), so that the logarithm of the indoor radon concentration can be written as a sum of logarithms of separately variable factors. The central limit theorem then implies that, if the individual factors are sufficiently variable across the population of homes, the resulting distribution of indoor concentrations will tend towards a normel disiribution (in log-space). Fig. 4 shows quartile plots of the logarithm of the concentration measurements in the six NH towns with mose than 25 measurements. Vertical scalcs for the different towns have been stifted to avoid overlap. On this type of plot, messurentents that are normally distributed fall on a straight lite, with the slope of the line determinod by the standard deviation. It can be seen from Fig. 5 that the log radon measurements in these lowns are approximately normatly distributed. with mildly variable standard deviations; in untransformed space, these lowns have approximately lognonmat distributions of measurements, with similar GSDs.

Fig. 5 presents all of the observed town GSDs as a function of the number of observations made in each lown. The weighted mean withitr-own GSD for all of the measured towns in the slate is 2.6 . If every town had the same true GSD of 2.6, then 95\% of the observed GSDs would fall between the two lines on the figure. The figure suggests that most of the observed varialion in GSDs is due to small sample sizes within lowns. In other words, it looks as though given enowgh measurerments, the GSD of the measured town screening measurements within most towns would be close to 2.6 for all towns in the state.

Based on previous experience (Price and others 1996, for example), the included explanatory variables are expected to have multiplicative rather than additive effects on indoor tadon concenirations, so it is computationally convenient to work with the logarithms of the radon measurements rather than with the meastrements themselves. We would like to write the log of the radon measurement in each horne as a sum of terms associated with various explanatory variables (NURE, presence of a basenent, genlogic type, what lown the home is in, etc) plus residual variation. A sligh complication is that the geologic type associated with each bome is unknown, since the only location information available is the town that the home is in, and many towns contain nore than one geologic type. In the absence of specific geologic knowledge 
associaled with each home, we fit a model in which each home's prediction has a contribution from each of the geologic types present in the town, weighted by prevalence, as explained below.

The fult stalistical model used to predict individual short-term radon measurement (SRM) radon concentrations follows: we write $Y_{j y}$, the natural logarithm of the SRM in home $i$, which is in town $j$, as

$$
Y_{i j}=\mathrm{X}_{i j} \cdot \beta+\sum_{k} f_{j k} \alpha_{k}+\theta_{j}+\varepsilon_{\mathrm{ij}}
$$

where $X_{i j}$ is a vector of explanatory variables for home $i$ in town $j$, and is known. The explanatory variables in $X$ are: the logerithm of the cown-average NURE measurements, the building type, above/below-grade measurement location, presence of below-grade living space, presence of a forced-air heating system, the domestic water supply, and a consiant term. The vector $\beta$ is composed of caefficients associaled with the explanatory variables in $X$; these coefficients are to be estimated from the data. The parameters $/ \alpha_{4} /$ are the "geologic unit effects" (discussed below), and allow some geologic units to have generally higher or lower radon levels than others do, by amounts to be estimated from the data; $f_{k}$ is the fraction of town $j$ thal is composed of gcologic lype $k$, and is decemined from digitized town and geology maps. The parameters $\left\{\theta_{j}\right\}$ are called the "town effects" (discussed below), and represent the amoun by which the logarithms of the true town GMs differ from the predicted values baseo on the other explanatory variables in the model. Finaliy, the logarithm of the radon measurement generally differs from its predicted value by a residual, $\varepsilon_{\mathrm{i}}$

The buikding type, forced-air heating, measurement location, and waler supply variables were cntered inlo the model as indicator ("dummy') variables. For example, there is a variable that takes the value of one for homes that arc apartments, and zero for homes that are not apartments. A sceond variable takes the value of one for mobile homes, and zero for othets. The coefficients associaled with these variables indicale the extent so which measurements in apartments and mobile homes, respectuvely, are elevated or depressed relasive to detached homes. Thus, a negative coefficient for "apartment" implies that indoor radon measturements in aparkments are lower than single family detached homes, after controlling for all of ahe other variables in the model. 
We assume the effects associated with the various geologic units are drawn from a normal distribution (in $\log$ space) with mean 0 and unkmown variance $\tau^{2}$ to be estimated from the chats:

$$
\alpha_{k}-N\left(0, \tau^{2}\right)
$$

The assumption that the geologic unit effects distribution has mean zero does not reduce the generality of the model, since any overall shift in the distribution of geologic unit effects is absorbed by the constant term in the model (see Equation 1). This is also true for the lown effects, discussed betow. The normality assumption is chosen partly for cormpulalional convenience, but also for substantive reasons: we expect a few geologic units to be associaled with highly elevaled or depressed indoor radon concentrations, while most of the rest are more "typical", there is no a priori reason to expect the distribution of geologic effects to be bimodal, for example. Model appropriateness and validation will be discussed in a later section.

We assume the town effects are drawn from a normal distribution with mean 0 and unknown variance $\mathbb{f}^{2}$ to be estimaled from the dala:

$$
\theta_{j} \sim N\left(0, \delta^{2}\right)
$$

The role of the town effects $\{\theta\}$ is as follows. If the regression coefficients $\{\beta\}$ and ail of the geologic unit effects $\{\alpha\}$ were known, then the town effect would be the residual between the town's true SRM In(GM) and the prediction based on the other expianatory variables. If the town effects were all close to zero, this would indicate that the predictions based on the other explanaiory variables were very accurace; if, on the other hand, lown effects tended to be large, this would indicate that predictions based on the pther explanatory wariables are subject to large errors. In the present analysis, the town effect estimate fulfills two roles: first, it allows the final prediction of the troe SRM values to be dircelly influenced by the observed town GM - if the predicion from the explanatory variables slone differs from the observation, the final prediction for the town (including the town effect) is a weighted averagc of the regrcssion-predicted value and the observed valuc. Sccondly, the typical size of the town effocis (as described by the variance $\hat{\delta}^{2}$, or retated measures) provides an cstimate of the variation of the truc SRM GMs about their regressionpredicted values. 
We assume that after the best coefficients for the explanatory variables $\beta, \alpha_{1}$ and $\theta$ are obtained, residual emor $\varepsilon_{i f}$ for a home is drawn from the distribution:

$$
\varepsilon_{\mathrm{r},}-N\left(0, \sigma^{2}\right)
$$

For any particuler model, the variance of the residuals, $\sigma^{2}$, provides an indication of model fil at the individual house level, wrth smaller values of $\sigma^{2}$ indicating betler predictions of individusl house log radon measurements.

The town effects variance $\delta^{2}$ and the residual variance $\sigma^{2}$ eddress different aspects of model fit. The town effects variance addresses the jssue of how we:l individual town means are predicted by the explanatory variables, but ignores within-town variance. The residual variance addresses the issue of how well the measurements in individual homes are predicled; since town effecis are included in all of our models, this parameter summarizes the variation between homes within lowns, and ignores variation between lowns.

In practice, of course, we do not know the values of the regression coefficients $\{\beta$, the geologic unit effects $\{\alpha\}$, nor the town effects $\{\theta\}$. We can, however, obtain estimates of all of these parameters through use of a statistical technique known as a mixed-effects regression. A Bayesian mixed effects regression is analogeus to an ordinary multivariate regression, except that some parameters - town effects $\{\theta\}$ and geologic unit effects $\{\alpha\}$, in this case - are nol allowed to vary independently, but are assumed drawn from common distributions. Such paramelers are known as "random effects", as opposed to the "fixed effects" $(\beta)$ which are trealed independently of one another as in a conventional regression; the combination of both lypes of parameters leads to the terminology "mixed effects regression." The term "Tandom effects" does not imply that the coefficients are actually assigned al random, merely that except for the dala included in the model we have no knowledge that tells us which effects should be high and which should be tow. Knowledge of the distribution from which pasamelers are drawn can kelp substantially in rainimizing the effects of statistical noise due to small sample sizes. For example, if we know the range in which most town GMs fall, we have sonte knowledge about the range of likely values even for a town with to observations at all. Detailed discussion of Bayesian mixed effects regression is outside the scope of the present paper. For a discussion of the topic as a whole, including computational and validation issues, see 
Gelman and others (1995); for an applicetion to predicting counly radon concentrations in Minnesota, see Price and others (1995).

The assumptions that town effects and geologic unit effects are drawn from common distributions for which the variance is estimaled from the data reduce the danger of substantially "overfitting" the model. In a conventional regression, if we include a regression coefficient for every town the coefficients will be estimated so that the model fits the observed town GMs exactly. Such a model would fit the data perfectly but would be highly unsatisfactory on substantive grounds. For example, considex Langdon, NH. This lown had only one observation, which was $174 \mathrm{~Bq} / \mathrm{m}^{3}(4,7 \mathrm{pCi} / \mathrm{L})$. Choosing a townt eftect estimate sp that the GM of this county is predicted to be $174 \mathrm{~Bq} / \mathrm{m}^{3}$ would fit the data perfectly. However, such a prediction would not be appropriate since it does not take into account the possibility that the sampled home had a particularly high, or low, measurement compared to tre lown GM. In facl, most wowns in the same geologic unit have observed $\mathrm{GMs}$ much lower than $174 \mathrm{~Bq} / \mathrm{m}^{3}$, so it seems likely that the single measured bome in Langdon, $\mathrm{NH}$, had a higher radon concentration than is typical in the town, at least for the period over which it was monitored. Bayes's theorem, upon which the approach of random (and mixed) eflects regression is based, puts this idea on a firm stalistical footing. Generally, the posteriot estimate for a random effect is a compromise belween the best-fit value and the expected value based on the distributional information for the parameter.

As it happens, under our model if the values of the variance parameters $\left(\boldsymbol{\tau}^{2}, \sigma^{2}\right.$, and $\left.\vec{\sigma}^{2}\right)$ were known exactly, the posterior estimales and uncertainties in the geologic effects, town effects, and olher coefficients conld be determined analytically from the data. But of course, the varience values are thenselves uncertain. In order to correclly incorporate this uncertainty, we perform many differcnl regressions, each with a different set of variances. We use a Monte Catlo method to sample from the distribution of likely values of the variance components, and then determine the regression coefficients and individual town and gcologic effects estimales) given that sel of variance values (sec Gelman and others 1995). Performing this procedure many times (several hundred) allows us lo take account of the uncertainties in the distributional parameters and the rcgression coefticients. 
The outcome of the series of regressions is a set of estimates, one for exch simulation, for every geologic province coefficient, every tows coefficient, and every regression coefticiens. Through coefficients of large magnitude, more influence is given to very reliable indicators of the true measurements, and through coefficients of small magnitude less influence is given to less reliable indicalors. The method empiricalty determines the coefficients thit best fit the data given the constraints of the model, and repetition of the regression with differenl variance estimates allows us to incorporale our uncertainty in each of the parameters. The variation in the estimates of a particular parameter indicates the uncertainty of that parameter's value. A set of posterior predictions, having a dișriobution of several hundread estimates for each observation, can be created by multiplying each vector of coefficients by the matrix of predictive variables used in the modes.

\section{Parameter Estimates from the Model}

Table 4 presents coefficient estimales rcsulting from a number of Bayesian mixed-effects model fits incorporating different classes of yariables. The regressions do not generate a point estimate for each coefficient, but rather a distribution of possible parameter yalues. The table shows the mean of this distribution, for each coefficient, and the last row in Table 4 consists of the standard errors of the estimates for the full model described above, denoted in the table as Model 10 . The uncertainties for the other medels are similar to those of Model 10.

Rather than showing alt 232 town coefficients and 9 geologic unit coefficients, we show only the estimaled varignce of their distributions, in Table 4. By definition (equations 2 and 3), the mean of these distributions is zero.

Although we are most interested in the results of the full model presented above, we have performed a variety of fits using yarious combinations of explanatory variables, to explore the extent to which the individual classes of variables add predictiwe power. The simplest modcl summarized in Table 4 is that of a mixed effects regression of the observed log SRM against a constant term, with lown cffects. This model uses the radon measurements alone to estimatc the between-town vartation in log radon measurements, withoul controlling for any exptanatory variables. The expression for this model is: 


$$
Y_{\mathrm{r}}=\beta_{0}+\theta_{j}+\varepsilon_{\mathrm{j}}
$$

As described in equation 3 , values of $\theta$ are assumed to have been drawn from a nomal distribution with a mean 0 and a variance of $\delta^{2}$ which is unknown. The estimale for $\beta_{0}$ was $4.43 \pm 0.05$ (in units of $\ln \left(\mathrm{Bq} / \mathrm{m}^{3}\right)$ ), and that for $\delta^{2}$ is $0.28 \pm 0.05$. In uniransformed space, this model assumes that the town GM radon concentrations are themselves draws from a lognomal distribution. The parameler estimales suggest thal the distribution of town GMs has a GM of $\exp (4.43)=84 \mathrm{~Bq} / \mathrm{m}^{3}(2.27 \mathrm{pCi} / \mathrm{L})$ and a GSD of $\exp (\delta)=1.7$. The lown effects coefficients produced by the procedure can be used to predict the individual town radon GM and GSD, though with considerable kss precision than those from the models that include additional expłanatory variables.

\section{Measures of Model Fit}

As discussed above, the variance of the residuals, $\sigma^{2}$, can be used to assess the predictive etror of the models. (Note that within the context of Eq. 5, which contains no individual-house variables, $\sigma^{2}$ can be thought of as the "within-town variance.") This quantily can be used to make a comparative measure of model fit for predicions at the individual house level similar to the " $\mathrm{K}^{2+1}$ used in conventional regressions (Bryk and Raudenbush 1992; Price and others 1995). This "effocive" $\mathrm{R}^{2}$ can be expressed as:

$$
R_{\text {radv }}^{2}=1-\frac{\sigma_{m}^{2}}{\sigma_{S R M}^{2}}
$$

where

$\sigma_{m}^{2}=$ unexplained variance of true $\ln ($ SRAM $)$ in model $m$, and

$\sigma_{\text {SRH }}^{2}=$ tolal variance of true [R(SRM).

Although the actual uncxplained vatiance and the total variances are unknown, we can estimate them from the data. $\sigma_{\mathrm{m}}^{2}$ can be estimated by the value $\sigma^{2}$ derived from the random-effects regression fits of a model. The total variance, $\sigma$ sha , can be estimated as the calculated variance of the actual $\ln (\mathrm{Rn})$ values for the 
NH sarvey The total variarce of the measured In(Rx) values in the 1774 homes in the anatysis is 12 $R_{\text {undar }}^{2}$ for Model 1, as shown in Table 4, is 018 This indicates thal about 18 㹈 of the vanatuos in the logarithms of the indindual radon measurements is attributable to vartation between towns, with the remander being due to varabon within towns

The varrance an lown effects $[\delta\rangle$ grves an indication of the extent to which the difference berween towns is explained by the varjation in the explanatory vansbles This metric can be thought of as the "unexplained between-town vanance" Model 2, which uncludes NURE, is defined by

$$
Y_{\mathrm{ij}}=\beta_{0}+\beta_{\mathrm{l}}+\log \left(N U R E_{\mathrm{l}}\right)+\theta_{\mathrm{j}}+\varepsilon_{\mathrm{j}}
$$

The estumated town effects varuance is $F$ of $022 \pm 004$ (corresponding to a GSD of Iown effects of $\exp (022)=16)$, slighly lower than the value of $028 \pm 004$ for Model 1 Recall that the town affecus $\{\theta\}$ proxy for sources of town-to-town vanaton that aren't upcluded in the model As such, we wouldn't expect lown-Jevel explanalory varıables such as NURE to explain withn-ıow varıance Additon of a variable could etrormously improve the model fit at the town level ( $t$ e could improve predicuon of the town GMs) without changing $R_{+ \text {+in }}^{2}$

The change in between-town vanance can be utulıed in the metrc $R_{\text {fow }}^{2}$ to compare how well different Giodels predict the Iown mean log fadon measuremenis This metric, also presented in Table 4, simtar to $R_{\text {that , is stmply }}^{2}$

$$
R_{\mathrm{own}}^{2} \equiv 1-\frac{\delta_{\text {aा }}^{2}}{\delta_{\text {tonn }- \text { ard }}^{2}}
$$

whete

$\delta_{\mathrm{w}}^{2}=$ unexplained between-lown vanance in model $m$, and

$\delta_{\text {rnwt-oth }}^{2}=$ lotal variance of town-effects, I $e$, vanance in Model 1 which has only town-effects and a constant Model 2 (Eq 7) has an $R_{\text {row }}^{2}$ of 019 This value can be compared to the simple $R^{2}$ of 009 from 
the regression of In(NURE) against observed In(GM SRM). The increase from 0.09 to 0.19 can be attributed to a reduction of the sample-noise present in the simple regression.

Model 9 shows a slight improvement in the prediction of indoor radon levels through the addition of the water-souree variables. Model 10, the full model described by Eq. 1, includes all of the fixed-effect variables, the town-effects and geologic unit effects. Adding the geologic unit effects to Model 9 does not change the $R_{\text {intiv }}^{2}$, which represents residual variation after controlling for all of the expianalory variables. This is expecled, since within any town all of the homes are assigned the same combination of geologic coniributions, in the absence of geologie information at the individual house level. However, Model 10 does show substantially reduced town effects compared with Model 9, indicating that the geologic variables do help exploin the variation of ridon measurements berween towns.

The estimated town effects variance is considerably lower for models that include the geologic units than for other models, although the unexplained variation is still substantial. For example, consider a town from which we have no monitoring data (and thus no information on its town effect), but for which we do have explanatory variables, including geologic information, fọr homes in the town. We expect our prediction of the town's GM to be off by aboul a factor of $\exp (\delta)=1.46$ (see Model 10 in Table 4), a considerable improvement over the factor of about 1.6 or 1.7 that would obtain without the geologic information, but still a Jarge expected etror.

The estimalcd town coefficients, which represent the amount by which mean town log radon measurcments differ from the value expected from the explanatory variables, are not presented fully in this paper. In Model 10, they range from $-0.56 \pm 0.23$ for Belmont, MH, $100.86 \pm 0.36$ for Clarksville, NH. In each case the listed standard error is a posterior interval tather than a classical confidence interval, an important distinction that is discussed below in the conlext of the geologic effects. A full listing of these coefficients is ayailable on the intemet web-site of the HIGB-RADON PROJECT at "hitp:/leetd.Ibl.gov/lEP/highradondhr.html." 


\section{Posterior Predictions of Town Genetrlc Means}

The last column in Table I presents predicled town GM SRM values calculated from the posterior distribution of Mode] 10 for a random selection of NH towns. Fig. 6 is a map of NH towns with shading used to depiet the posterior predictions of GM SRM values for all 249 towns in New Hampshire, for detached single-family dwellings with occupied basements (i.e., $\mathrm{MH}=\mathrm{AP}=\mathrm{BGL}=\mathrm{MAG}=0$, see Table 4 for identification of these abbreviations), no forced-air furnace ( $\mathrm{i} . \mathrm{e}_{\text {, }} \mathrm{FAF}=0$ ), ant a municipal waler source (i.e., $\mathrm{DW}=\mathrm{SW}=\mathbf{0}$ ).

We present the results in this way since for most towns we have little data on the fraclion of homes in each town that are nol single-famity detached homes, thal have forced-air healitg, etc. All we know are these fractions for the homes in our dats set, and the small number of hornes in most towns makes the true Iractions very uncerlain. Predicied GMs for other types of homes can be calculated by multiplying by the appropriate factor. For example, from Table 1 the posterior prediction of GM SRM for single-family detached dwellings with municipal water and no foreed air furnace in Madison, $\mathrm{NH}$ is $214 \times /+1.39 \mathrm{~Bq} / \mathrm{m}^{3}$ (note inultiplicative error). To calculate the predicled GM for, say, mobile homes that use municipal water and have no forced-air heating-and which are typically measured above grade, with no below ground living space - wc must adjust for several factors: mobile homes have different (lower) measurements that do single-family homes, homes without below-ground living space have somewhat different (lower) measurements than homes with below-ground living space, and measurements above grade are substantially lower than those made below grade. No adjusiment is necessary for heating lype or water supply, since these match the "standard" home for which the predictions were generated. The required adjustment Faclot, then, (from Table 4) is:

$\exp \left(-0.73_{\mathrm{MH}}-0.52_{\mathrm{MAO}}-0.10_{\mathrm{BGL}}\right)=\mathrm{e}^{-1.35}=0.26$

Thus the predicted GM for mobisle homes in Madison is $0.25 \times 214 \mathrm{~Bq}^{\prime} \mathrm{m}^{3}=55 \mathrm{~Bq} / \mathrm{m}^{3}$. Note the subscripts in Eq. 9 refer to the variable for which the coefficients apply. 
The lowest and highest predicted NH town GMs aze for Antrim $\left(34 \mathrm{~Bq} / \mathrm{m}^{3}\right.$ or $\left.1 \mathrm{pCi}, \mathrm{GSD}=1.3\right)$ and Harts Lacaion ( $558 \mathrm{~Bq} / \mathrm{m}^{3}$ or $15 \mathrm{pCi} /, \mathrm{GSD}=1.5$ ), respectively. Posterior predictions for all towns in NH using Model IO are listed in Appendices I and It.

\section{Model Validation}

In this section, two methods are used to assess how well the assumptions of the model agroe with the data The first method, known as "posterior predictive checks," simulates data from the foll-Bayes model and compares them to the observed data. The seconot method, "cross-yalidation", is to run a full-Bayes modelfit on a subset of the data and use the results to prectict the radon concentrations in the bones which were excluded from the dataset. A comparison of the predicted radon levels in these houses to the observed levels provides a measure of how well the model is working.

\section{Posterior Predictive Checks.}

Bayesian posterior predictive checks have been suggested as a means to assess the ability of a model to produce realistic sinulations. Such checks can point out possible model violations, as described fuliy by Gelman and others (Gelman and others 1995). Posteriot predictive checks are performed as follows: we fit our statistical model to the dala, thus generating prediclions and uncertuinties for each of the coefficients (including geologic and town effects) as well as for the variance components. Using these predictions, we then generate predictions for each tome's SRM as well as the uncertainly in this quantily. Satngling from this distribution for each home, we construct an "imputed" or "simulated" data set. This data set can be thought of as another "possible" data set that could have occurred, if another New Hampshire survey were conducted with another sel of homes with the sarme explanatory yariables (but not teeccstarily the same radon levels) as the homes in the actual survey. A significant discrepancy between the simulated data set and the actual data may indicate a modet violalion.

This procedure may seem circular, after all, our predictions and variance estimales are generated from the datz, so aren'l our impuled data guatanteed to agree with the actual data? The answer is no, becatse the predictions and variance estimates do not just depend on the datz, but also on the assumptions buith into the 
model. If these assumptions are seriously in error-for instance, if the nomality assumptions of the assumption of uniform variance in the residuals are very wrong-che imputed data can differ greatly from the actual dala. Seme test statistics are more sensitive than others to such model chpices, with effects of non-normality or heteroskedasticity (non-uniform variatce) showing up most strongly in the tails of the distribution of measurements.

Fig. 7 presents a set of histograns of the distributions of imputed 10th, 20th, 50th, 80th, 90th, and 99th percentile SRM values from model 10 (using 1200 draws from the posterior distribution). These hislograms depict the variation in predicted values at their percentile. For example the upper-left hislogram in Fig. 7 shows that under the model, the 10th pereentile measured value is expected to be within about 1 or $2 \mathrm{~B} q \mathrm{~m}^{3}$ of $21 \mathrm{~B} 4 / \mathrm{m}^{3}$. Each histogram in the Figure has a solid vertical fine indicating the appropriate percentile of the observed SRM distribution. The I0kh percentile SRM in the sctual data is just over 22 $\mathrm{Bq} / \mathrm{m}^{3}$, which is towards the high side of the expected distribution from the model: As the "Bayes p-value" of 0.13 shown on the figure indicates, in only $13 \%$ of the simulation draws was the imputed 10 th percentile SRM as high or higher than in the actual data So if the model is "correcl" then a IOth petcentile measurement as high as $22 \mathrm{~Bq}^{\prime} \mathrm{m}^{3}$ is somewhat unusual. Extreme Bayes p-values - very closc to 0 or I indicate that the observed data are very unexpected under the model, suggesting the model assumptions may be substanially incorrect. This may or may not represent a serious problem, depending on the sensitivity of the parameters of interest to the problems with the model.

In the present case, the imputation does noc indicate any serious problems for the bulk of the data: although the Bayes p-values for the J0h, Soth, and 80 th percentile are all forther from 0.5 than we would like, the discrepancies between imputation and actual data are very small in absolute 1erms, of the order of a few $\mathrm{B} 4 \mathrm{~m}$ '. For example, in the case of the 50 th percentile, the Bayesian p-value of 0.94 indicates a fairly poor fit, but on substantive grounds this means litle since the $5 \mathrm{~Bq} / \mathrm{m}^{3}(0.1 \mathrm{pCi} / \mathrm{L})$ difference between the observed value (approx. $82 \mathrm{~Bq} / \mathrm{m}^{3}$ ) and the median of the posterior distribution (approx. $87 \mathrm{~Bq} / \mathrm{m}^{3}$ ) is of to consequence.

Howevet, the posterior prediclions from Model Jo clearly underestimate the observed s9th percentile of radon concentrations. In fact, in only about $0.2 \%$ of the 1200 simulations was the 99 th percentile SRM as 
high as the observed value of $1550 \mathrm{~B} / \mathrm{m}^{3}$ ! On substantive grounds too, the model also appears to fail to eapture these tail concentrations: the difference between the median prediction and the true value is several hundred $\mathrm{Bg} / \mathrm{m}^{3}$. The model assumptions tha1 lead to these discrepancies are probably either the assumption of homoskedasticity (equal variance) within towns and geologic provirsces, or the assumption of normality of the residuals in log space. This problem only occurs for the highest few percent of measurements, and this failure of the model to predict individual high homes does not have a signifucant influence on the estitnates of the individual town and geologic unit effects because these estimates are dominaled by the bulk of the data. Moditying the model to belcer fit the high tail of measurements wovid lead to increased computational complexily and would make the results harder to interprel, without substastally affecting the estimates of the geologic effects and town effects. For this reason, we retain our simple model and merely note that it would not be a good idea to use the model to prodict, say, the number of homes in the state in which a screening measurement would exceed $750 \mathrm{~Bq} / \mathrm{m}^{3}(20 \mathrm{pCi} / \mathrm{L})$.

\section{Model Validation Using a Restricted Data Set.}

In order to search for whes violations of the model, it validation dala set was crealed by randomly removing $80 \%$ of the data from the 27 towns in the NH survey with 15 or more observalions. Most of these towns are from the highly populous southeastern portion of the state. Model 10 was re-run with the reduced dataset $(\mathrm{N}=1320)$. Observed data from the retraining 455 homes from the previously welj-sampled towns wert then available for comparison with the model prodictions for thosc homes. Fig. 8 shows the refationship between observed and predicted town mean In(radon) values for the validalion dataset. The diagonal line in this figure represents the theoretical periect fit (slope $=1$, inletcept $=0$ ) for this comparison. The observed mean for each town was calculated directly from the full survey dataset. The predicted mean for each town was calculated from the individual town means from the 1200 sets of posterior predictions. The error bars for each point (each town mean) in the figure indicale \pm 1 standard enror, calculated from the distribution of posterior predictions.

Note that only 3 of the 27 distributions of predicted mean town la(radon) levels are more than I standard error away from the observed value, in contrast to the 9 or so towns that are expected to differ by that 
amount. That is, the model appears to predict better than it is expected to (the stated uncertainties are too Jarge). Investigation of the model predictions reveals the explanation: mast of the well-sampled towns are from the southeastem part of the stalc, and one of the two major geologic types there-G438, Granitic plutons, metasedjmentary rocks-shows much less relative variation between towns than do other geologic types. The model assumes that all geologics are oqually variabie (in log spact), and thus cxpects more unpredicted variation between towns than is present in this geology. The model could be modified (with Gifficully) to estimate separately the town effects variances for the different geologies, but we have not pettormed this task Only two geologic provinces show evidence of substantially atypical variability: G43B (mentioned above) which is much less variable than most geologies, and 0546, Jurassic-Cretaceous rocks of the While Mountain and New England-Quebec igneous succession, which is much more variable than monst for reasons discussed below. Fitting a more conplicated heleroskedastic (multi-variance) model would provide somewhat belter predictions for towns in these provinces, but the main effect would to change the error estimates: posterior intervals tor towns in G436 would be narrowed, and those for 0546 would be widened, compared to the predictions generated from Model 10 .

\section{Interpretation of Geologic Unit Effects}

The poslerior estimates and uncettainties of the geologic coefficients $(\alpha)$ from Model 10 are included in Table 3. Recalt that NURE is included in this model, so these geologic coefficients represent the effects of the various geologic provinces after accounting for variation in surficial radium concentration. Many of the coefficient estimates are consistent with zero, in the sense that the standard crors overlap zcro. Howcrer, there is an important distinction between the posterior intervals given in the table and classical confidence intervals. The classical eslimates would be chosen to best fit the data, and overiap of the confidence intervals with zero might then lead one to conclude that the estimates are not "significant" and that all of the true coefficients are likely to be closer to zero, and might all be zero. The posterior estimates shown in the table, though, have already been "pulled" towards zero through Bayes' theorem (recall that the posterior estimate is a compromise between the best-fil estimate and the mean of the distribution of effects, which is zero in this case). If the statistical model we have fit is appropriate then each coetficient's true value is 
equally likely to be higher or fower than the posterior estimate. Thus the fact that many of the standard errors overlap zero should not be taken to indicale that the geologic effects overall are small.

Ac least two of the nine provinces are associated with large effects on radon measurements. The "glacial deposits and marine sediments" geology (ID number G4]1) is present in the Northeastern part of the state and has a high estimated coefficient ( $1.09 \pm 0.52$ ), indicating a substantial association with elevated indoor radon levels even afier controlling for other risk factors such as NURE, building type, water source, town effects, etc. Tows GM radon levels for this province can be expected to be a factor of about exp(1.1) = 3 times higher than the average for other towns with similar house construction and surface uranium concentration. Silurian-Devonian inlrusive rocks (ID numbes G54t) are associated with substantially depressed levels, about a factor of 0.4 times as high as the median geology. Two additional provinces (ID numbers G546 and G561) are also associated with substantial estimated effects. Several of the other geologies night also have large effects, but the available data are not sufficient to determine which (if any). Fig. 3 maps the geographic distribution of geologic units with an index signifying the strength of the coefficients.

The variance of the distribution from which the geologic province effecks were drawn, $t$, is quite uncerlaift, with values as low as 0.2 and as high as $\$ .4$ being marginally consistent with the data. However, the exact value of this variance is not particularly informative in the present case, since only a small mumber (9) of different geologies are presen-we are interested in the effects associated with these particular geologies, not the distribution of "possible" geologic effects from which these values were drawn. The assumed "hyperdistribution" from which the geológic effects were drawn is a mathematical fiction thai belps us quantify our uncertainties in the individual geologic effects.

The fact that some of the geologic provinces are associaled with substantially elevated (or depressed) radon concentrations does not necessarily mean that this association is causal. With a few exceptions the gcologic provinces icnd to be fairly compact atd localized, so that any strong spatial correlation could manifest itself in large geologic province effects. In fact, a fit that uses the 10 counlies in New Hampshire instean of the geologies - primarily a spatial assignment, although the county boundaries do follow some gcographic fealures - performs as well statistically as the fit based on the 9 geologic provinces. The county 
boundaries allow for one important feature that the geologic provinces do not: in the central latitodes of the stalc, iowns cast of roughly the North-South mid-kine have much higher radon measurements than do towns west of that line, even after controlling fot NURE and house construction variables. The division between high and low town GMs corresponds approximately with the border between Carroll and Grafton counties, so the county variables can capture this diffetence in radon levels. In contrast, geologic province G544 contains boh low-radon towns to the west and high-radon lowns to the east. This is the rcason for the large lown tffects varjance within this geologic province, which was noled above: the high and fow towns cannor be predicted from geologic province, NURE, and the other explanatory variables, so the only remaining source of variability is the town effects. On the other hand, elsewhere in the stale the geologic provinct boundaries perform betler than do the county boundaries, particularly in the southeastern and northern portions of the state. In short, the reason for the demonstrated relationship between the geologic provinces and the indoor radon measurements is unclear.

Also unciear is the extent to which the abnormally low vatiance between towns in geology G438 is causal, us opposed to being the result of, say, more uniform housing slock in this fainty urbanized area.

\section{Discussion and Conclusions}

A Bayesian mixed-effects linear regression mode] has been used to predict short-term induor radon concentrations in residences in New Hanpshire with more precision than would be possible using available monitoring data only. Vatidation checks indicate mincor model violations that do not strongly influetice estimates of the main pararneters of interest, which are town GMs and the coefficients associated with geologic provinces and other explanatory variables. Geologic indicator variables wert included in some models, as were predictive variables that are believed to be directly related to indoor radon concentralions: Lown-avefuge NURE data are a measure of radium in the surface soil. Siruclure-specific variables including building type, below-grade living space, foreed air furnace heating system, and water supply source are all variables likely to affect the equilibrium indoor radon concentration were included. Since radon generally eniers through the lowest floc of the home measurements are expected to be higher if made below grade. 
One assumption upon which the model relies is that the distributions of indoor tadon concentrations within cowns are lognormally distributed. This assumption appears to be approximately correct, based on the observed distributions of several well-sampled NH lowns. The posterior predictions of town GMs from the full model range from $34 \mathrm{~Bq} / \mathrm{m}^{3}$ (1 pCi/h) with a multiplicative uncerlainly of $1.3,10574 \mathrm{~Bq} / \mathrm{m}^{3}$ (15 $\left.\mathrm{pCi}\right)$ with a multiplicative urceriainty of I.S.

Model 2, is which only town effects and NURE are used to predict short-tercin mon concentrations, suggests that NURE alone does considerably better than suggested by the value of $R^{2}$ in the conventional regression, with $R_{\text {conwt }}^{2}=0.18$ compared to the conventional regression estimate of $R^{2}=0.09$ : the obserwed GMs vary about their true values due to small sample variation, depressing the conventional $R^{2}$ eslimate.

Addition of gealogic province informalion, as in Models 3,4 , and $\mathbf{1 0}$, substantially improves prediction of the town GMs compared to models that exclude this information, with $R_{\text {town }}^{2}$ of the order of 0.5 rather than between 0.15 to 0.20 . However, as discussed previously the reasons for this improvement are not clear-it may be that the geologic provinces merely capture some spatial variation that is due to ofther causes not inchuded in the model.

There is considerable variation in town GMs across the statc-indeed, as can be scen from the estimate of $R_{\text {moln }}^{2}$ in the first line in Table 4 , abou $\mathbf{1 8 \%}$ of the variance in individual house $\log$ radon measurements is altributable to the fact that some towns have elevaled concentrations compared to others. Improvements in the fut are atso seen when characleristics of the individual homes are included, leading to an increase of $R_{m d v}^{2}$ from 0.18 to 0.26 . The coefficient estimates are reasonable in both magnitude and direction: measurenents made above grade are considerably lower than those made below grade, and neasurements in mobile homes are much lower than those in single family homes, by a faclor of exp(0.73) $=2$, compared to single-family homes monitored above grade. The coefficient of $0.20 \pm 0.06$ for drilled wells indicates that residences with this water source have 20 percent higher radon values than those with a municipal water source.

Forced air furnaces are associaled with about a $15 \%$ reduction in measured concentrations, but this finding must be interpreted with some care. For instance, it may be that forced-air furnaces cause increased mixing 
between the basement and upper floors, and are thus associaled with decreased radon concentrations in the basement (whore most measuremenls were made) while increasing concentrations upstairs. The present data, which do not contain measurements for multiple floors in the same homes, are not sufficient for us to investigate this possibjility.

The approach used in this paper has provided a means to use cadon survey screening data and other explanalory variables to more precisely predict short-term indoor tadon concenirations and town GMs. Bayesian modeling helps reduce the effects of sampling variation allowing more precision than possible in analyses based on available monitoring alone. The approach appears to work well in prodicting short-term indogr radon distributions al a scale as small as individual towns. The inclusion of geologic unit information has been usefwl in identifying high-radon areas and serves to increase the prediclive power of the model, bul results are ambiguous with respect to the causal relationship belween the included geologic province information and the radon measurements. More information on the development and results of these methods is available through e-mail to "high-radon above.

\section{Acknowledgments}

Dr. Daviơ S. Chase of the State of New Hampshife, Departnent of Health and Human Services, Radon Seclion provided us with the NH State Radon Survey data and reviewed this manuscript. We are indebied to Linda Gundersen and Randall Sclumenn of the USGS for their assistance in providing digital files containing gcological dala for the $\mathrm{NH}$, and for their assistance in interpretation of the goologic data. We would also like to thank Harold Wollenberg and Maureen Lahiff for their revicws of the paper. This work was supporicd by the Directo, Office of Energy Research, Officc of Heatth and Environmental Restarch, Human Health and Life Sciences Research Division of the U.S. Department of Energy under contract DEAC03-76\$F00098. 


\section{References}

Bryk AS and SW Raudenbush (1992) Hierarchical Linear Models, Newbury Park: Sage Publications.

Duval, JS, Jones WJ, Riggle FR, and JA Pitkin (1989) "Equivalent Uranium Map of the Conterminous United States" U.S. Geological Surrey.

Gelman A, Carlin J, Stern H, and Rubin D (1995) Bawesian Dala Analysis, New York, NY.: Chapman and Hail.

Gundersen LC and Schumann RR (1993) Preliminary Geologic Radon Potential Assessment of New Hampshire, Geologic Radon Potential of EPA Region 1, ed. RR Schumann. U.S. Geological Survey.

Nazaroff WW, Doyle SM, Nero AV, and Sextro RG (1987) "Potable Water as a Source of Airtorne ${ }^{2 x_{\text {Rn }}}$ in U.S. Dwellings: a Review and Assessmenl," Health Physics 52 (3): $281-295$.

Nero AV, Gadgil AJ, Nazaroff WW, and Revzan KL (1990) "Indoor Radon and Decay Products: concentrations, causes, and control strategies," Lawrence Berkeley National Laboratory.

Nemo AV, Schwehr MB, Nazanoff WW, and Revzan KL (1986) "Distribution of Airborne Radon-222 Concentrations in U.S. Homes," Stience 234992.997.

Pirie JC and Haninglon JE (1989) "New Hampshire Radon Survey 1987-1989," New Hampshire Division of Public Health Services and the Govenor's Office.

Pirie JC and Hanington JE, (1990) "New Hampshire Radon Survey 1987-1990 Addendum." New Hampshire Division of Public Health Services and the Governer's Office.

Price PN, (1996) "Predictions and Maps of County Mean Indoor Radon Concentrations in the Mid-Alantic States," Lawrence Berkeley Nacional Laboratory.

Price PN and Nero AV (1996) "Joint analysis of long- and short-term radon monitoring data from the Northern U.S." Environment Inierthational, November.

Price PN, Nero AV, and Gelman A (1996) "Bayesian Prediction of Mean Indoor Radon Concentrations for Minncsota Countics,". Health Physics 71 (6): 922-936.

Revzan KL, Price PN, and Nero AV (1996) "Bajesian Analysis of the Relationship between Indoor Radon

Concentrations and Predictive Variables in US. Houses," Lawrence Berkelcy Natiotal Laboratory. 


\section{Tables}

Table 1 . Summary of screening data, average surficial uranjum concentrations (NURE) and posterior predictions from Model 10 for 25 of the 259 New Hampshire towns.

\begin{tabular}{|c|c|c|c|c|c|}
\hline Town Name & $\begin{array}{c}\text { Number } \\
\text { of } \\
\text { Homes }\end{array}$ & $\begin{array}{c}\text { Observed } \\
\text { GM } \\
\left(\mathrm{B} / \mathrm{m}^{3}\right)\end{array}$ & $\begin{array}{l}\text { Observed } \\
\text { GSD }\end{array}$ & $\begin{array}{l}\text { NURE } \\
\text { (ppm U) }\end{array}$ & $\begin{array}{l}\text { Predicted GM } \\
\text { for Houses with } \\
\text { Basement } \\
\left(\mathrm{Bg} / \mathrm{m}^{3}\right)\end{array}$ \\
\hline WINDSOR & 1 & 15 & & 2.02 & $40 \times 4+1.44$ \\
\hline WEBSTER & 7 & 31 & 2.04 & 158 & $38 \times \div-1.31$ \\
\hline CENTER HARBOR & 2 & 32 & 1.38 & 1.77 & $45 \times 4+1.39$ \\
\hline WARNER & 6 & 36 & 3.98 & 1.99 & $53 \times 4+1.32$ \\
\hline MONROE & 4 & 43 & 1.78 & I. 49 & $51 \times / 41.35$ \\
\hline SUPEE & 5 & 43 & 2.22 & 3.01 & $73 \times / 41.32$ \\
\hline MEREDITH & 12 & 46 & 2.38 & 2.17 & $77 \times 4+1.28$ \\
\hline HINSDALE & [1] & 51 & 2.44 & 1.88 & $82 \times+1.26$ \\
\hline ALEXANDRIA & 4 & 59 & 1.25 & 2.84 & $74 \times<1.33$ \\
\hline NEWINGTON & 5 & 59 & 2.95 & 2.50 & $104 \times \div 1.33$ \\
\hline ANDOVER & 7 & 65 & 4.93 & 2.11 & $7 B \times 1=1.29$ \\
\hline EASTON & 4 & 76 & 2.02 & 1.46 & $62 \times+1.37$ \\
\hline BENTON & 5 & 77 & 2.56 & 1.74 & $82 \times+1.32$ \\
\hline MONT VERNON & 6 & 78 & 3.00 & 3.33 & $79 \times+1.31$ \\
\hline GOFFSTOWN & 14 & 82 & 2.49 & 3.15 & $96 \times 1+1.24$ \\
\hline PEMBROKE & 9 & 88 & 3.26 & 1.76 & $87 \times \div 1.28$ \\
\hline WINCHESTER & 5 & 92 & 8.10 & 1.93 & $80 \times 4+1.34$ \\
\hline MIDDLETON & 4 & 127 & 2.12 & 2.87 & $123 \times / 1.36$ \\
\hline COLEBROOK & 8 & 127 & 2.89 & 1.40 & $90 \times / 41.31$ \\
\hline CANDIA & 13 & 141 & 2.25 & 3.28 & $129 \times+1.26$ \\
\hline BRADFORD & 2 & 159 & 5.42 & 1.66 & $59 \times / 1.41$ \\
\hline STARK & 4 & 270 & 6.06 & 2.07 & $168 \times 1+1.36$ \\
\hline GORHAM & 16 & 323 & 3.45 & 2.56 & $281 \times 1+1.24$ \\
\hline WOODSTOCK & 4 & 427 & 2.23 & 2.43 & $129 \times 4+1.39$ \\
\hline MADISON & 4 & 589 & 2.04 & 3.59 & $209 \times 4+1.39$ \\
\hline
\end{tabular}


Table 2. Summary of home types in the New Hampshite radon survey.

\begin{tabular}{|c|c|c|}
\hline & $\begin{array}{c}\text { number of } \\
\text { homes }\end{array}$ & $\begin{array}{l}\text { percent } \\
\text { of homes }\end{array}$ \\
\hline Total number of homes surveyed & 1814 & 100 \\
\hline Number of homes in the present analysis & 1775 & 98 \\
\hline single Jamily detached & 1661 & 91 \\
\hline multi family & 85 & 5 \\
\hline mobile home & 68 & 4 \\
\hline basement is used as living space & 565 & 31 \\
\hline no basement $o r$ basement not lived in & 1249 & 69 \\
\hline monilored in basement (if any) & 1485 & 82 \\
\hline no basement or not monitored is basement & 329 & 18 \\
\hline forced-air healing system & 584 & 32 \\
\hline other heating system & 1230 & 68 \\
\hline low'n water supply & 639 & 35 \\
\hline shallow well & 305 & 18 \\
\hline drilled well & 831 & 46 \\
\hline unknown & 39 & 2 \\
\hline home buill before 1900 & 266 & 15 \\
\hline $1900-1950$ & 267 & 15 \\
\hline $1950-1974$ & 439 & 24 \\
\hline $1974-1990$ & 842 & 46 \\
\hline
\end{tabular}


Table 3. Groupings of New Hampshize geologic types used in the radon predictive model and geologic effects coefficients derived from Model 10.

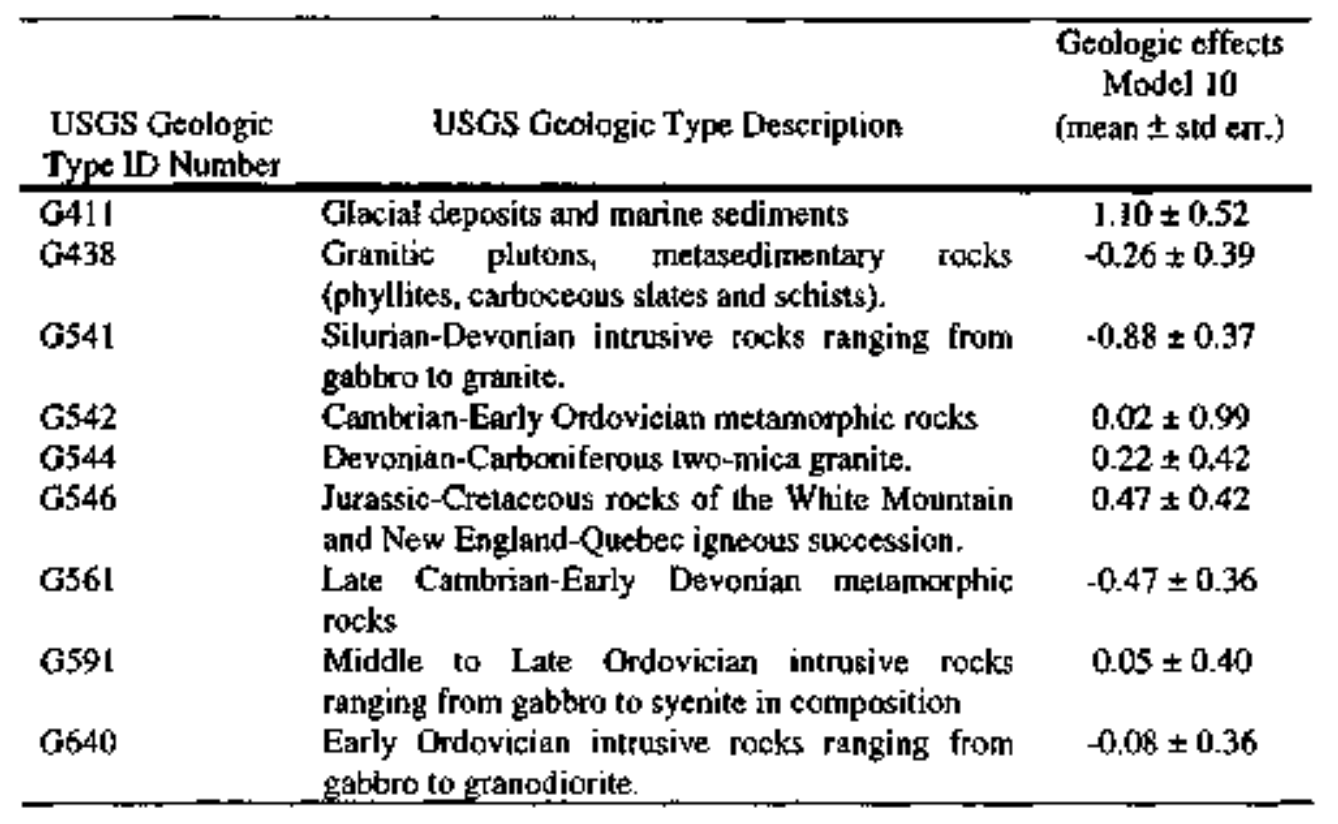


Table 4. Coeficient estimales from Bayesian mixed-effects modeIs for various combinations of explanatory variables.

\begin{tabular}{|c|c|c|c|c|c|c|c|c|c|c|c|c|c|c|c|c|}
\hline \multirow[b]{2}{*}{$\begin{array}{l}\text { Model } \\
\text { Number }\end{array}$} & \multirow[b]{2}{*}{$\begin{array}{l}\text { Const. } \\
\ln \left(\mathrm{Bq} / \mathrm{m}^{3}\right)\end{array}$} & \multicolumn{8}{|c|}{ Coefficients of tixed-effects explanatory variables ${ }^{2}$} & \multicolumn{5}{|c|}{ Variances } & \multicolumn{2}{|c|}{ Measures of fit } \\
\hline & & $\begin{array}{c}\text { Eog } \\
\text { of } \\
\text { NURE }\end{array}$ & $\begin{array}{l}\text { Mobile } \\
\text { Home } \\
\text { [MH] }\end{array}$ & $\begin{array}{c}\text { Apart- } \\
\text { ment } \\
{[\mathrm{AP}]}\end{array}$ & $\begin{array}{l}\text { Meas. } \\
\text { Above } \\
\text { Grade } \\
\text { [MAG] }\end{array}$ & $\begin{array}{l}\text { Below } \\
\text { Ground } \\
\text { Living } \\
\text { Space } \\
\text { [BGL] }\end{array}$ & $\begin{array}{l}\text { Forced } \\
\text { Air } \\
\text { Furnace } \\
\\
\text { [FAF] }\end{array}$ & $\begin{array}{c}\text { Drilled } \\
\text { Wel] } \\
\text { [DW] }\end{array}$ & $\begin{array}{l}\text { Shallow } \\
\text { Wellt } \\
\text { Spring } \\
\\
\text { [SW] }\end{array}$ & $\begin{array}{c}\bar{T} \\
\mathrm{Et}\end{array}$ & $\exp (\delta)$ & $\begin{array}{c}\text { Geol } \\
\text { Eff }\end{array}$ & $\begin{array}{l}\text { logic } \\
\text { ects }\end{array}$ & Residuals & $\begin{array}{c}\text { Effective } \\
\mathbf{R}^{2} \\
\text { resid. } \\
R_{\text {sutv }}^{2}\end{array}$ & $\begin{array}{l}\text { Effective } \\
\mathbf{R}^{2} \\
\text { town } \\
R_{\text {dunt }}^{2}\end{array}$ \\
\hline I & 4.43 & & & & & & & & & $0 . \overline{28}$ & 1.69 & & & 0.99 & 0.18 & \\
\hline 2 & 3.70 & 0.87 & & & & & & & & 0.22 & 1.61 & & & 0.99 & 0.18 & 0.19 \\
\hline 3 & 4.82 & & & & & & & & & 0.14 & 1.45 & 1.37 & 3.23 & 0.99 & 0.17 & 0.51 \\
\hline 6 & 3.80 & 0.94 & .0 .80 & -0.09 & -0.55 & -0.07 & & & & 0.23 & 1.62 & & & 0.90 & 0.25 & 0.16 \\
\hline 7 & 3.83 & 0.92 & -0.73 & .0 .08 & -0.53 & & -0.12 & & & 0.23 & 1.62 & & & 0.90 & 0.25 & 0.17 \\
\hline 8 & 3.86 & 0.93 & -0.73 & -0.09 & -0.55 & 0.08 & -0.13 & & & 0.24 & 1.62 & & & 0.90 & 0.25 & 0.15 \\
\hline 9 & 3.80 & 0.91 & .0 .75 & -0.09 & -0.54 & -0.09 & -0.13 & 0.16 & -0.06 & 0.25 & 1.65 & & & 0.89 & 0.26 & 0.10 \\
\hline 10 & 4.23 & 0.74 & .0 .73 & -0.12 & -0.52 & -0.10 & -0.12 & 0.20 & 0.01 & 0.14 & 1.45 & 0.67 & 2.67 & 0.90 & 0.26 & 0.50 \\
\hline $\begin{array}{l}\text { SD' } \\
\text { Model } 10\end{array}$ & 0.39 & 0.18 & 0.14 & 0.11 & 0.07 & 0.05 & 0.05 & 0.06 & 0.08 & 0.03 & & $1.1 \overline{8}$ & & 0.03 & & \\
\hline
\end{tabular}

${ }^{2}$ Coefficients are actuatly the mean of 1200 coefficients estimates mede using Fuil Bayes regressions. Bracketed codes are abbreviations for the variables which are used in the text.

'Effective $\mathbf{R}^{2}$ resid. ( $R_{\text {matr }}^{1}$ ) is calculated as I-[(var(residuals)/var(In(observed radon scteening measurements))]

${ }^{t}$ Effective $R^{2}$ town ( $R_{\text {tnun }}^{2}$ ) is caleulated as $1-\left[\left(\hat{\delta}^{2}\right.\right.$ from Model $\left.n\right)$ ( $\hat{\delta}^{2}$ from Model 1$\left.)\right]$.

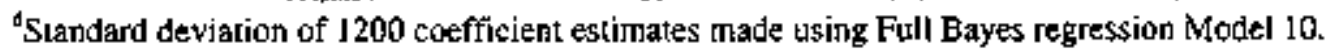




\section{Figure Captions}

Fig. 1. The distribution of short-term radon screening measurements collected in the New Hampshire Radon Survey.

Fig. 2. The natural logarithm of observed gcomelsic mean short-term radon screening measurements for 232 towns in New Hampshire plotted against town-average strficial uranium concentrations (NURE).

Fig. 3. Geologic map of New Hampshire with distinct geologic units indexed by random-effects geological unit coefficients from Model 10.

Flg. 4. The distributions of natural logarithm of measured indoor redon screening measuremenls for six New Hampshire towns. Note that the values of these observaljons have been shifted by constant amounts in order to superimpose them on the same figure.

Fig. S. Observed town geometric standard deviations of short-term radon screening measurements plotled as a function of the number of observations in each town. The supenmposed curves indicale the $95 \%$ confidence interval for the hypothesis that the trae GSD for New Hampshire town tadon screening measurements is 2.6 .

Fig. 6. Posterior predictions of town GM indoor radon concentrations for homcs with basements. The GM values presented here are not the "true" values but oniy one of many possible sets of predictions drawn at random from distributional data. 
Fig. 7. Bayesian posterior predictive checks of 1200 simulations of Model 10. The predictive checks have been conducted al the J0h, 20th, 50th, 80th, 90th, and 99th percentiles. The superimposed line on each hislogran of posterior distributions is the measurement al the percentile in question, from the New Hampshire Radon Survey. The p-value presented is a Bayesian p-value, as discussed in the text. For example, the firs! plot shows that the l0th-percentile measurement was about $22 \mathrm{Bodm}^{3}$ (vertical fine), and that simulated data from the posterior distribution had 10th-percentite values between about 19 and 22.5 $\mathrm{Bq} / \mathrm{m}^{3}$ most of the time (histogtam), with the simulated 10th-percentile value exceeding the actual measurement about $] 1 \%$ of the time $(p=0,11)$.

Fig. 8. A validation set was creatcd by remoying 80 for of the data from the 27 best-sampled towns in the New Hampshire Radon Survey. This figure shows predicted town In(geonetric mean) radon concentrations (using Model 10) for these towns, ploted as a function of the towns' observed radon concentrations as indicaled by the validation set. The diagonal line tepresents a "petfect fit". The error bats indicate one standard etror of the disttibutions of predicted town concentrations. 
Figures

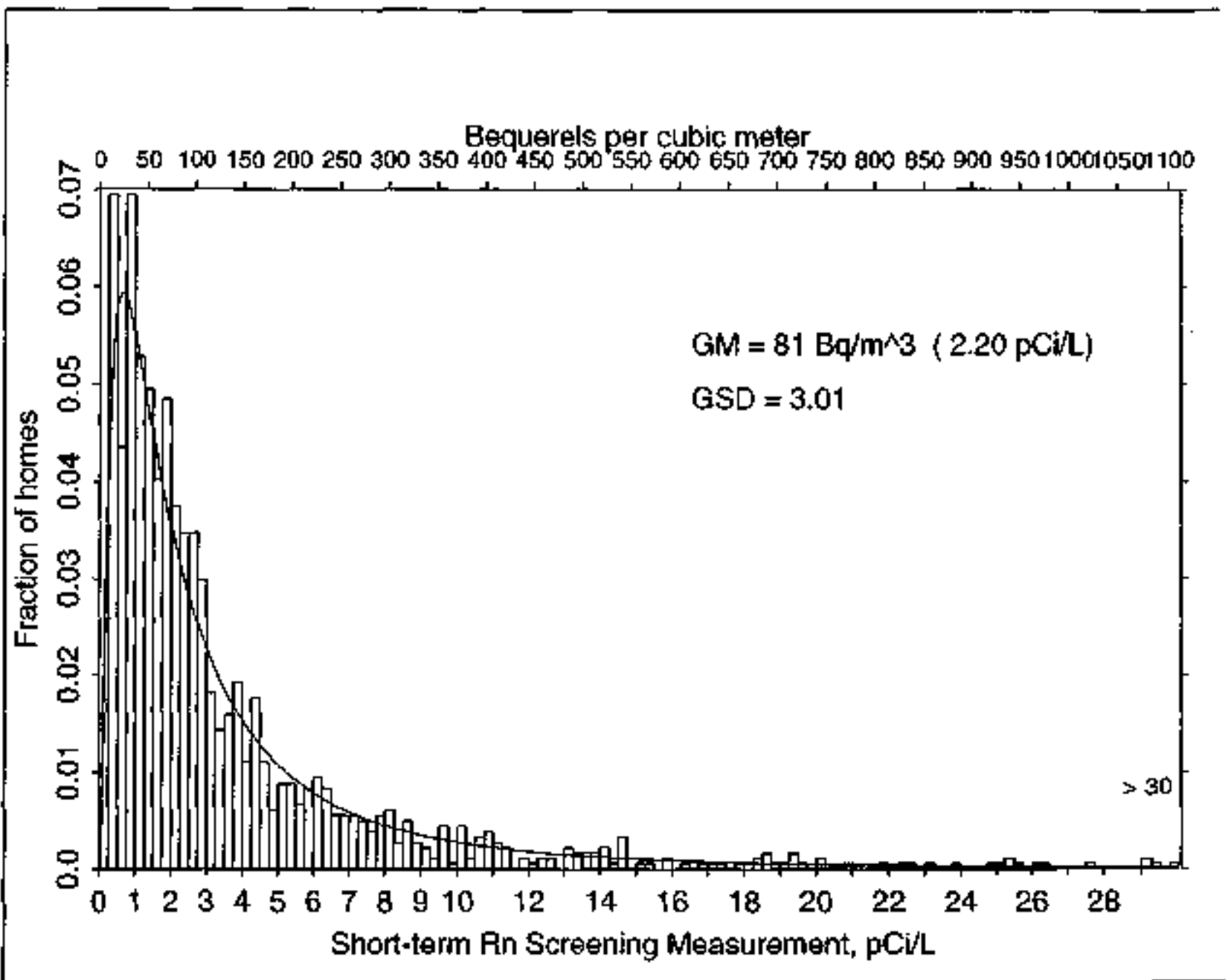

Fl. 1. The distribution of shom-term radon screening measurements collected in the New Hampshire Radon Survey. 


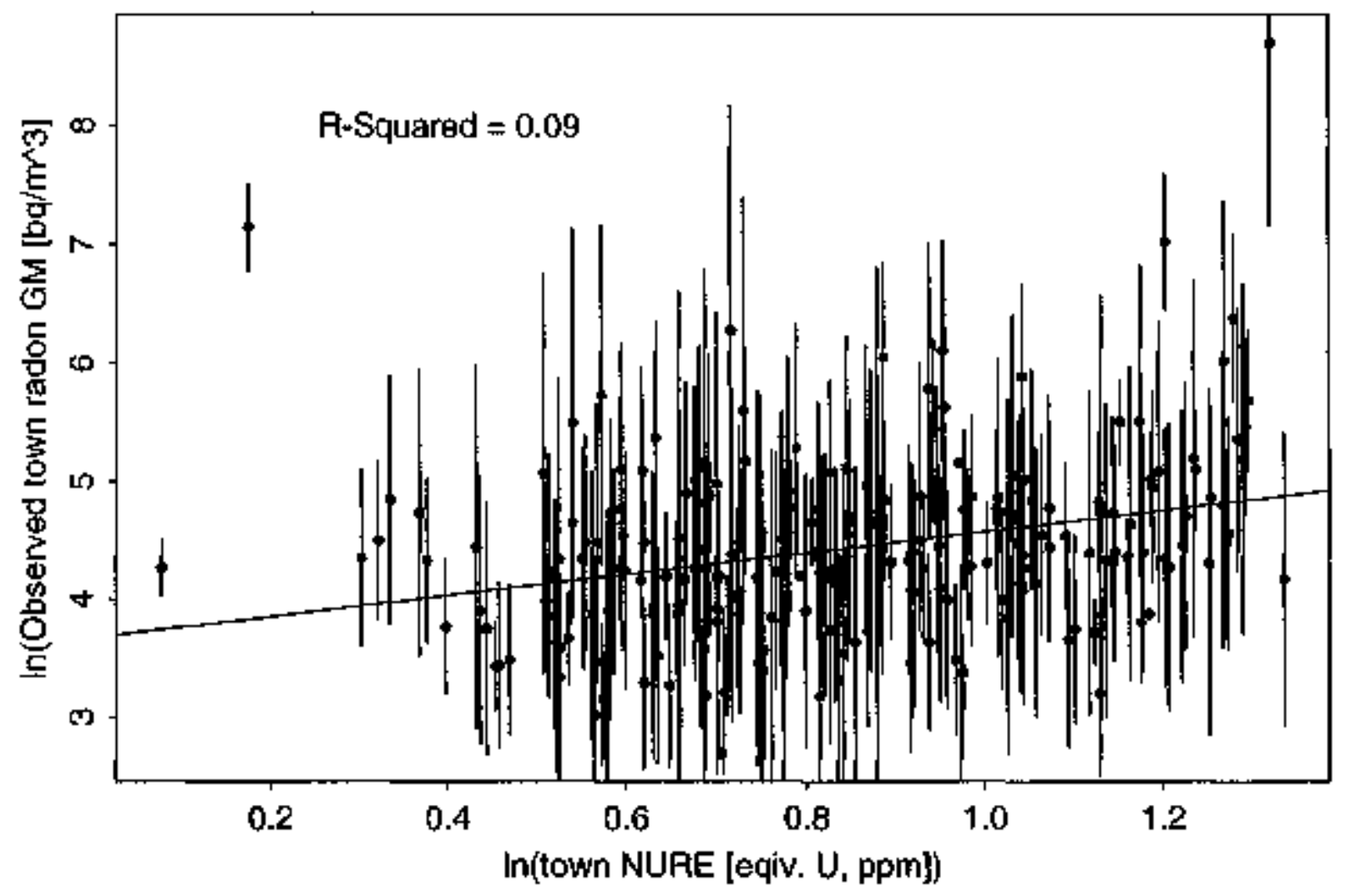

Fig. 2. The nalaral logarithm of observed geometric mean short-ten radon screening measurements for 232 towns in New Hampshire plolted against town-average surficial uraniutn concentrations (NURE). 


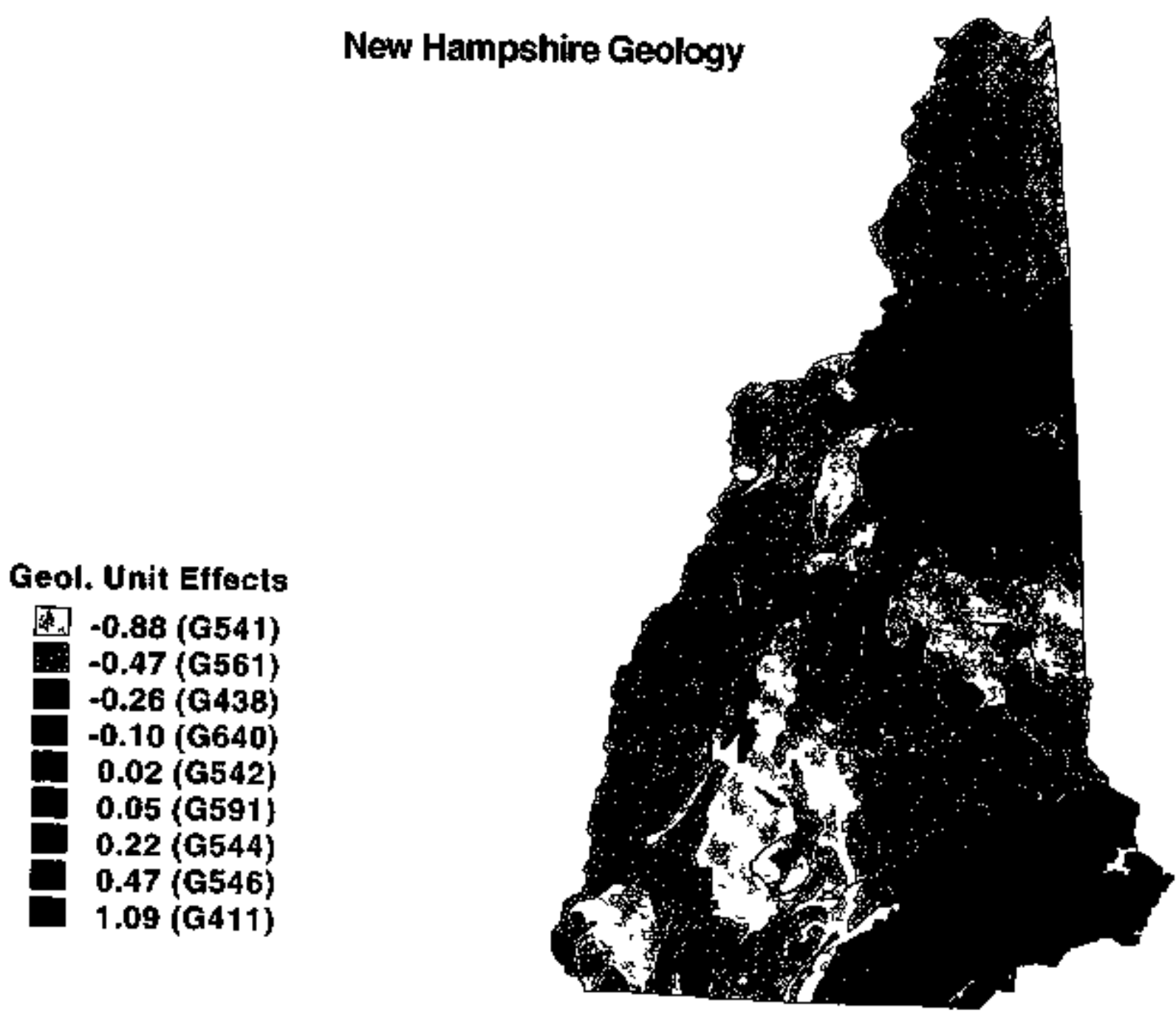

Fig. 3. Geologic map of New Hampsture wath distunct geologic units Indexed by random-effects geologtcal unit coefficients from Model 10 


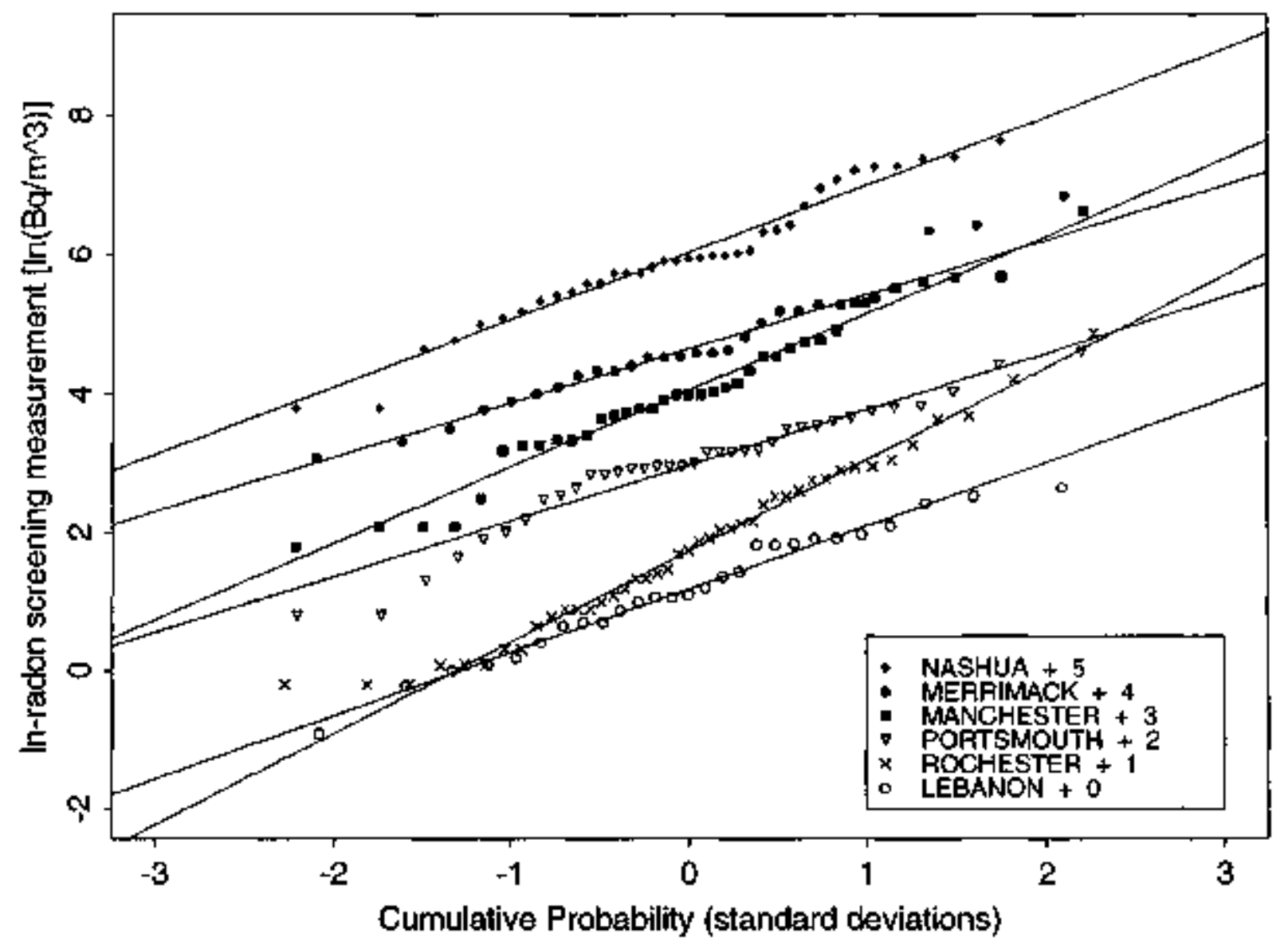

Fig. 4. The distributions of natural logarithm of measured indoor radon screening measurements for six New Hampshire towns. Note that the values of these obscrvations bave been shifted by constant amounts in order to superimpose them on the same figure. 


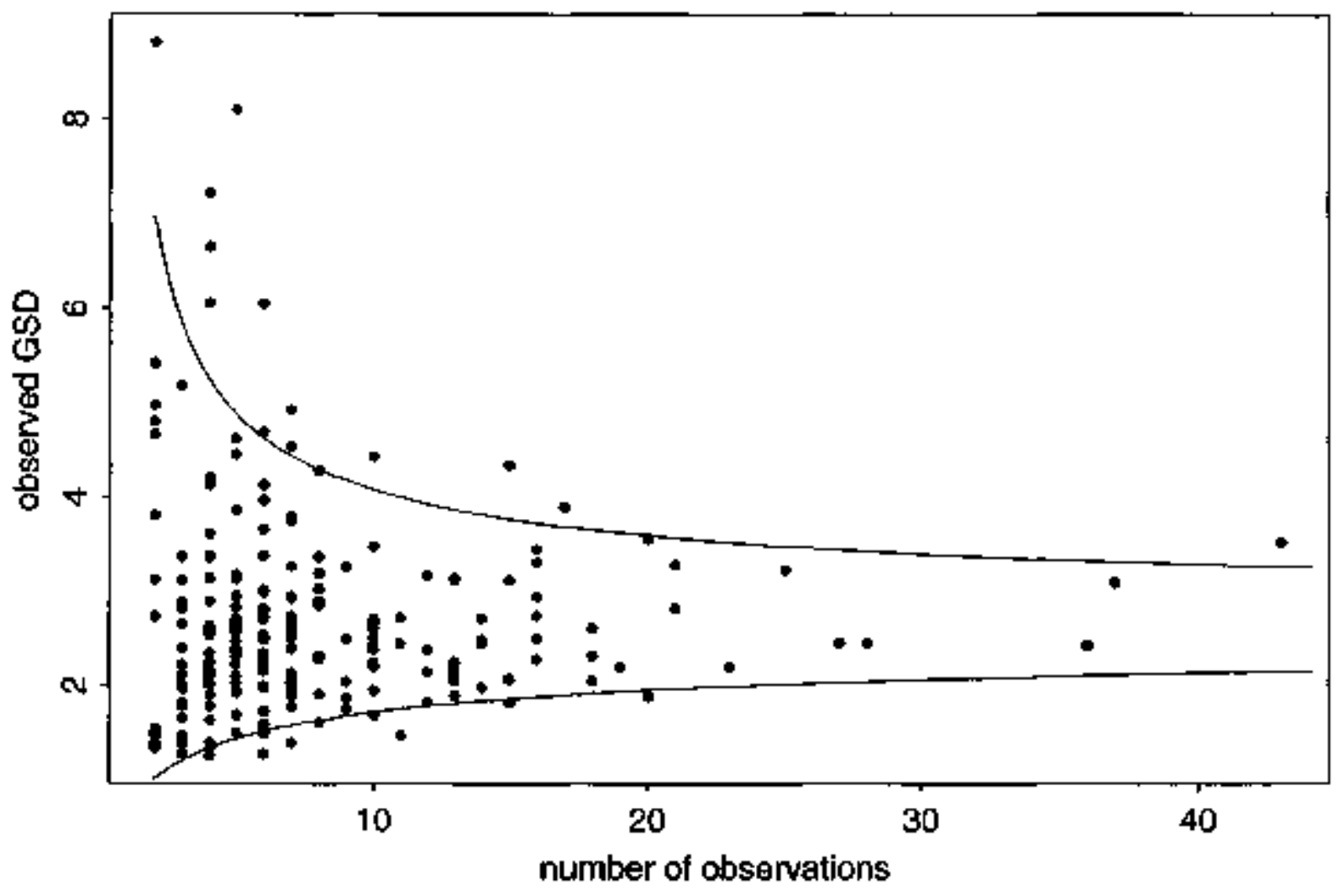

Fig. 5. Observed town geometric standard devations of short-lecm radon screenung measurements plotted as a function of the number of observations in each town The superimposed curves indicate the $95 \%$ confidence interval for the hypothesis that the true GSD for New Hampshtre town radon screening measurements is 26 


\section{Predicted Town Ga Radon Concentrations: NH Homes with Basements}

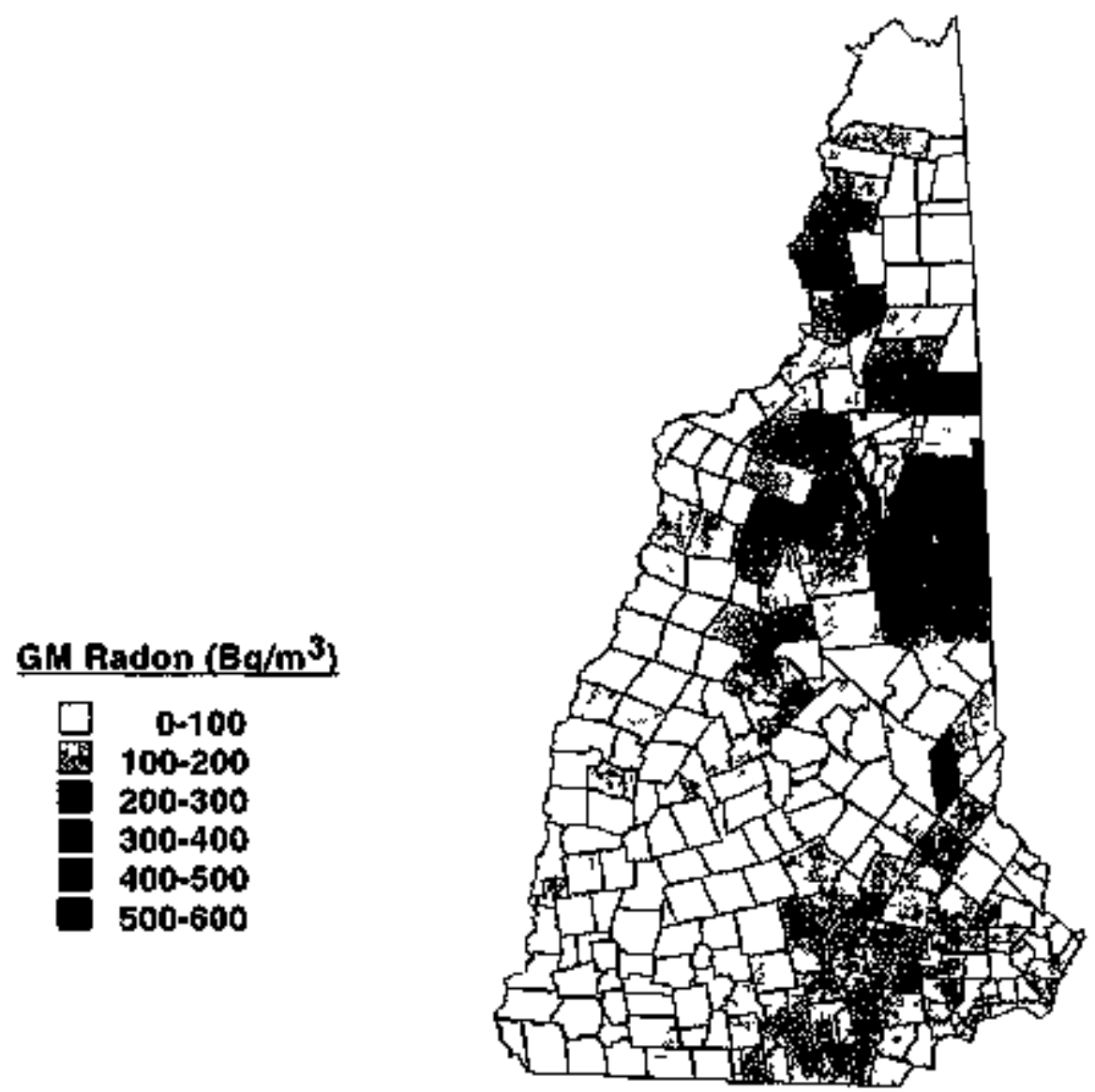

Flg. 6. Posterior predictions of town GM indopr radon concentrations for homes with basements The GM values presented here are not the "troe" values but only one of many possible sets of predichions drawn at random from distributional data 

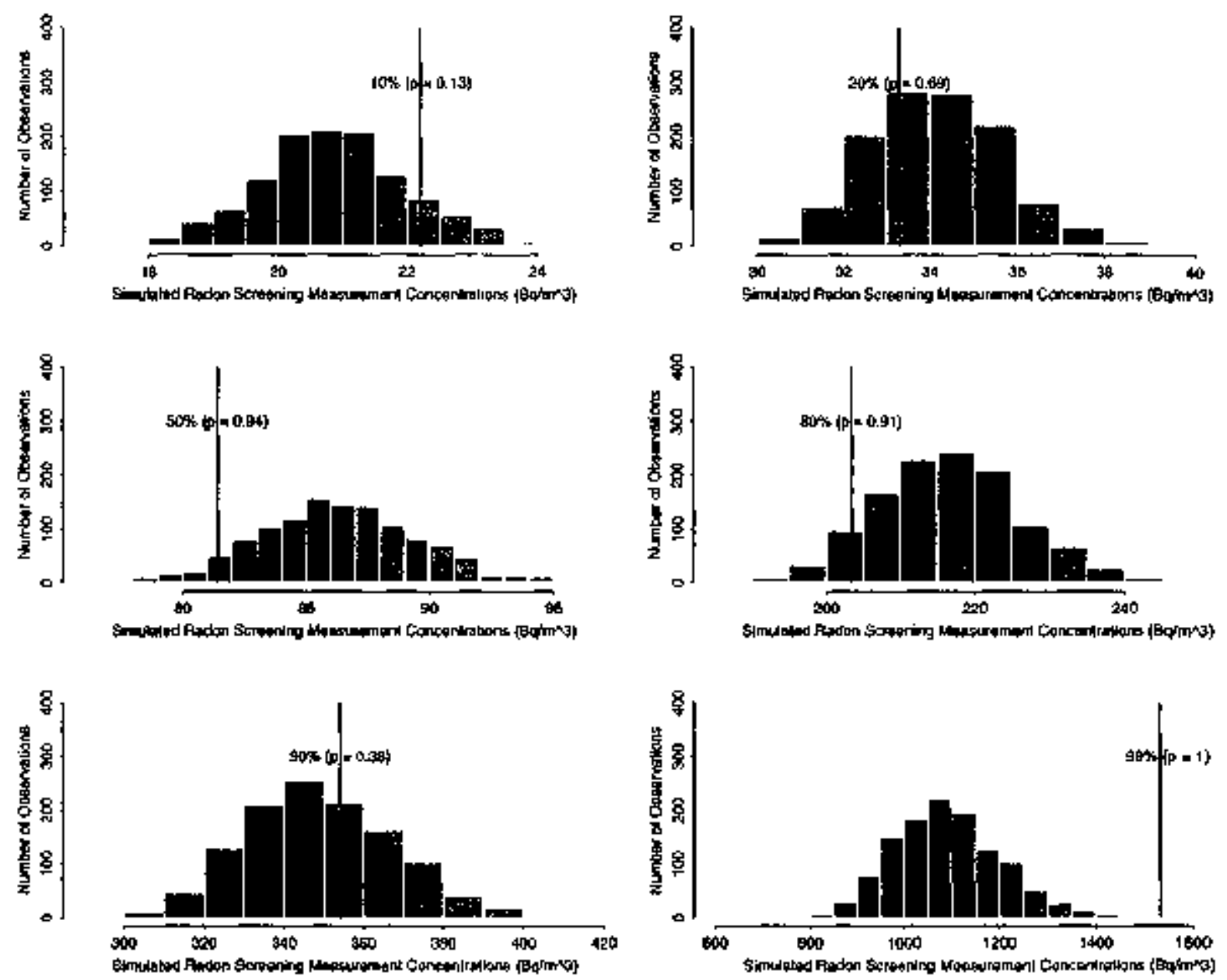

Fis. 7. Bayesian posterior predictive checks of 1200 simulations of Model 10. The prediclive checks have been conducted at the 10th, 20th, 50th, 80th, 90th, and 99th percentiles. The superimposed line on each histogram of posterior distributions is the measurement at the percentile in question, from the New Hampshire Radon Survey. The p-value presented is a Bayesian $p$-valse, as discussed in the text For example, the fust plot shows that the lOth-perecntile measurement was about $22 \mathrm{~Bq} / \mathrm{m}^{3}$ (vertical line), and that simulated data from the posterior distribution had loth-percentile values between about 19 and 22.5 $\mathrm{Bq} / \mathrm{m}^{3}$ most of the time (histogram), with the simulated 10th-percentile value exceeding the actual measurement aboul $11 \%$ of the time $(p=0.11)$. 


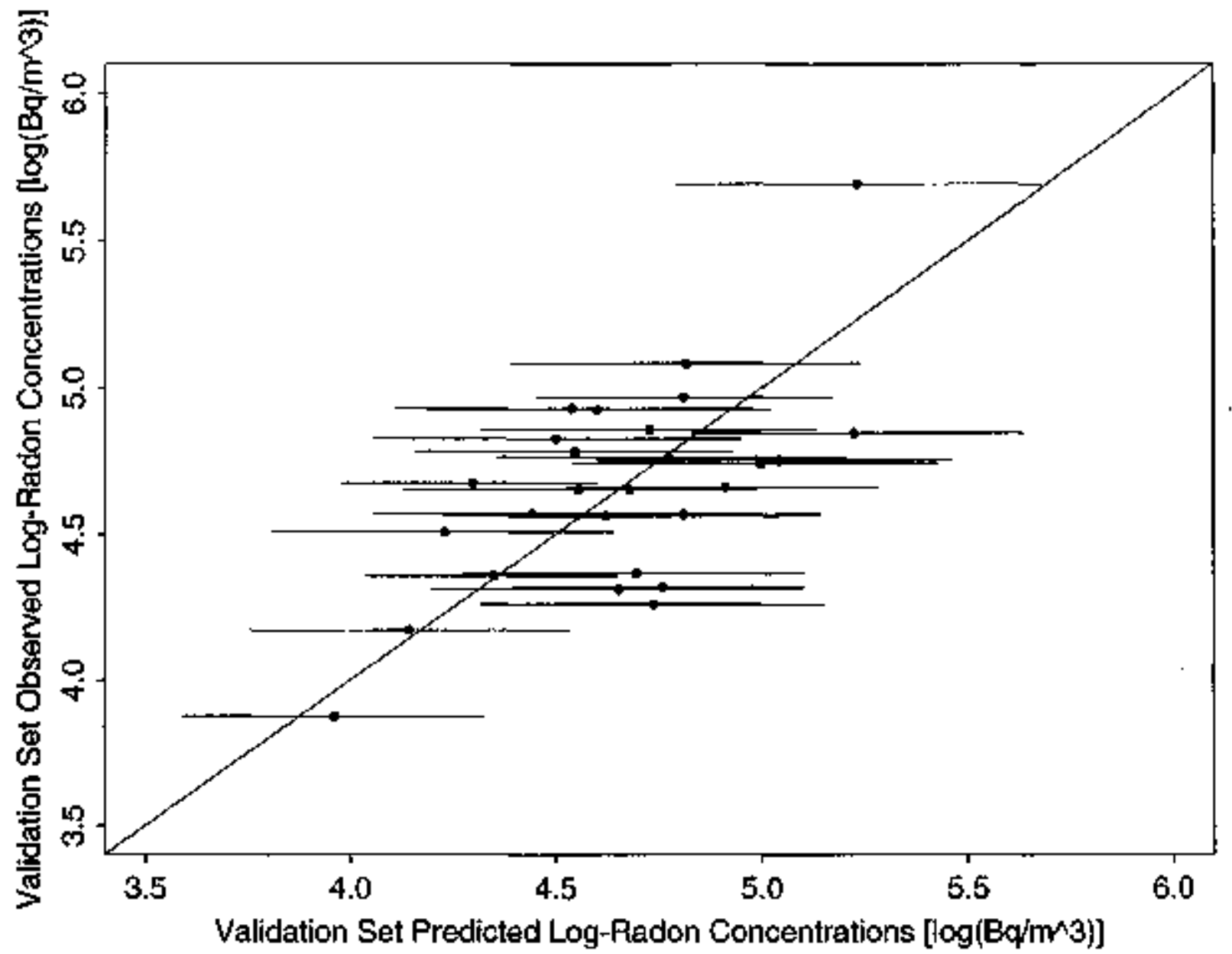

Fig. 8. A validation set was created by removing $80 \%$ of the data from the 27 best-sampled towns in the New Halzpshife Radon Survey. This figure shows predicted town In(geonetuic mean) radon concentrations (using Model 10) for these towns, plotted as a function of the lowns'observed radion concentrations as indicaled by the validation sct. The diagonal line represents a "perfest fit". The entor bars indicate onc standard etror of the distributions of predicted town concentrations. 
Appendix I. Posterior predictions finm Model lo for the 232 towns included in the NH State Radon Survey. These predictions are for the Town GMs of detached single-family dweltings with occupied basements, w FAF, and a municipal water sosirce.

Predicted GM

for Houses with

Tounn $\quad$ Basement

$\left(\mathrm{Bg} / \mathrm{m}^{3}\right)\left(x^{\prime}+\mathrm{sid}\right.$ err)

\begin{tabular}{lr}
\hline ACWORTH & $80(1.31)$ \\
ALBANY & $289(1.42)$ \\
ALEXANDRIA & $74(1.33)$ \\
ALJENSTOWN & $168(1.31)$ \\
ALSTEAD & $74(1.34)$ \\
ALTON & $73(1.33)$ \\
AMHERST & $113(1.23)$ \\
ANDOVER & $78(1.29)$ \\
ANTRIM & $34(1.32)$ \\
ASHLAND & $118(1.32)$ \\
ATKINSON & $118(1.22)$ \\
AUBURN & $111(1.25)$ \\
BARNSTEAD & $115(1.37)$ \\
BARRINGTON & $11(1.28)$ \\
BARTLETT & $273(1.41)$ \\
BATH & $72(1.30)$ \\
BEDFORD & $137(1.22)$ \\
BELMONT & $55(1.27)$ \\
BENNINGTON & $38(1.31)$ \\
BENTON & $82(1.32)$ \\
BERLIN & $123(1.19)$ \\
BETHLEHEM & $141(1.33)$ \\
BOSCAWEN & $50(1.39)$ \\
BOW & $97(1.23)$ \\
BRADFORD & $59(1.41)$ \\
BRENTWOOD & $119(1.31)$ \\
BRIDGEWATER & $97(1.35)$ \\
BRISTOL & $94(1.31)$ \\
BROOKFIELD & $105(1.36)$ \\
BROOKLINE & $96(1.33)$ \\
CAAN & $140(1.33)$ \\
CAMPTON & $74(1.39)$ \\
CANDIA & $129(1.26)$ \\
CANTERBURY & $77(1.33)$ \\
CARROLL & $169(1.34)$ \\
CENTER HARBOR & $45(1.39)$ \\
CHARLESTOWN & $77(1.31)$ \\
CHATHAM & $289(1.45)$ \\
CHESTER & $148(1.28)$ \\
CHESTERFIELD & $68(1.31)$ \\
CHICHESTER & $104(1.40)$ \\
CLAREMONT & $71(1.30)$ \\
CLARKSVILLE & $112(1.44)$ \\
COLEBROOK & $90(1.31)$ \\
COLUMBLA & \\
& $160)$ \\
&
\end{tabular}

Predicted GM for Houses with Basement $\left(\mathrm{B} g / \mathrm{m}^{3}\right)(x / 4 \mathrm{std}$ err $)$

\begin{tabular}{lr}
\hline CONCORD & $99(1.22)$ \\
CONWAY & $269(1.31)$ \\
CORNISH & $63(1.32)$ \\
CROYDON & $112(1.33)$ \\
DALTON & $87(1.33)$ \\
DANBURY & $71(1.39)$ \\
DANVILLE & $185(1.34)$ \\
DEERFIELD & $122(1.23)$ \\
DEERING & $43(1.31)$ \\
DERRY & $112(1.21)$ \\
DIXVILLE & $60(1.39)$ \\
DORCHESTER & $69(1.35)$ \\
DOVER & $96(1.27)$ \\
DUBLIN & $60(1.33)$ \\
DUMMER & $80(1.37)$ \\
DUNBARTON & $127(1.30)$ \\
DURHAM & $101(1.27)$ \\
EAST KINGSTON & $140(1.31)$ \\
EASTON & $62(1.37)$ \\
EATON & $238(1.36)$ \\
EFFINGHAM & $90(1.36)$ \\
ELLSWORTH & $70(1.43)$ \\
ENFIELD & $93(1.34)$ \\
EPPING & $123(1.30)$ \\
EPSOM & $95(1.35)$ \\
ERROL & $78(1.39)$ \\
EXETER & $79(1.28)$ \\
FARMINGTON & $146(1.32)$ \\
FITZWTLLIAM & $70(1.34)$ \\
FRANCESTOWN & $48(1.37)$ \\
FRANCONI & $96(1.37)$ \\
FRANKLIN & $78(1.24)$ \\
FREEDOM & $193(1.41)$ \\
FREMONT & $113(1.35)$ \\
GILFORD & $90(1.28)$ \\
GILMANTON & $72(1.31)$ \\
GILSUM & $85(1.32)$ \\
GOFFSTOWN & $96(1.24)$ \\
GORHAM & $67(1.24)$ \\
GOSHEN & $87(1.31)$ \\
GRANTHAM & $65(1.34)$ \\
GREENFIELD & $(1.32)$ \\
GREENLAND & $95(1.30)$ \\
GREENVILLE & $1.33)$ \\
GROTON & \\
&
\end{tabular}


Appendix II. Posteriot predictions from Model 10 for the 27 lowns not included in the NH State Radon Survey. These predictions are for the Town GMs of detached single-fannily dwellings with occupied basements, no FAF, and a municipal water source.

Predicted GM

for Horses with

\begin{tabular}{|c|c|}
\hline Town & $\begin{array}{c}\text { Basement } \\
\left(\mathrm{B} / \mathrm{m}^{3}\right)\left(x^{\prime}+\text { std err }\right)\end{array}$ \\
\hline ATKINSON \& GILMANTON & $38(2.40)$ \\
\hline BEANS GRANT & $68(1.76)$ \\
\hline BEANS PURCHASE & $71(1.83)$ \\
\hline CAMBRIDGE & $35(2.18)$ \\
\hline CHANDLERS PURCHASE & $54(1.75)$ \\
\hline CRAWFORDS PURCHASE & $72(2.18)$ \\
\hline CUTTS GRANT & $58(1.82)$ \\
\hline DIXS GRANT & $36(2.37)$ \\
\hline ERVINGS LOCATION & $33(1.72)$ \\
\hline GRAFTON & $52(1.89)$ \\
\hline GREENS GRANT & $66(1.87)$ \\
\hline HADLEYS PURCHASE & $87(2.07)$ \\
\hline HALES LOCATION & $100(2.39)$ \\
\hline KILKENNY & $76(2.30)$ \\
\hline LOW\&BURBANKS & $52(1.67)$ \\
\hline MARTINS LOCATION & $62(1.68)$ \\
\hline MLLSFIELD & $44(1.76)$ \\
\hline NEWFIELDS & $74(2.40)$ \\
\hline ODELL & $47(1.62)$ \\
\hline PINKHAM'S GRANT & $60(1.88)$ \\
\hline SARGENTS PURCHASE & $66(1.78)$ \\
\hline SECOND COLLEGE & $38(2.38)$ \\
\hline SUCCESS & $34(1.62)$ \\
\hline THOMPSON\&MESERVE & $65(1.77)$ \\
\hline UNORGANIZED TERRITORY & $91(2.11)$ \\
\hline WATER VILLE VALLEY & $81(2.02)$ \\
\hline WENTWORTHS LOCATTON & $36(2.10)$ \\
\hline
\end{tabular}




.

